\title{
Penilaian Autentik: Penerapan dan Dampak Kualitas Hasil Belajar Terhadap Mata Kuliah Bahasa Inggris
}

\author{
Helmy Sahirul Alim \\ Jurusan Teknik Listrik Industri, Politeknik Negeri Madura \\ Sampang - Madura, Indonesia \\ E-mail: hsahirul86@gmail.com
}

\begin{abstract}
This study aims to find out how the application of authentic methods and what their impact on the quality of student learning outcomes. This research method used descriptive qualitative where the data obtained is presented based on facts in the field. The subjects of this study were 3 lecturers and 32 first grade students who were taking Bahasa Inggris 2 (English 2) in Teknik Bangunan Kapal (Ship Building Engineering) in Politeknik Negeri Madura. 3 aspects of authentic assessment are the focus of this study to assess student learning processes. These three things are the assessment of student performance (performance), assessment of student attitudes (attitude), and product assessment (product). Based on the three aspects above, the researcher found that in its application this method was very suitable to be used in the Polytechnic environment considering that the learning patterns were very focused on real cases that occurred with all the solutions to the problems. As for the learning outcomes that have been found in this study are the activeness or the participation of students in using English in solving problems that have been predetermined by researchers. This is because in its application authentic assessment does not focus on traditional assessment such as examinations.
\end{abstract}

Keywords: Authentic assessment, evaluation, learning outcomes

\begin{abstract}
ABSTRAK
Penelitian ini bertujuan untuk mengetahui bagaimana penerapan metode autentik dan apa dampaknya terhadap kualitas hasil belajar mahasiswa. Metode penelitian ini menggunakan deskriptif kualitatif; data yang diperoleh dipaparkan secara apa adanya dan berdasarkan fakta yang ada di lapangan. Subjek penelitian ini adalah 3 orang dosen dan 32 mahasiswa tingkat satu yang sedang mengikuti mata kuliah Bahasa Inggris 2 di Jurusan Teknik Bangunan Kapal di Politeknik Negeri Madura. Tiga aspek penilaian autentik menjadi fokus dalam penelitian ini untuk menilai proses belajar mahasiswa. Ketiga hal tersebut adalah penilaian kinerja mahasiswa (performance), penilaian sikap mahasiswa (attitude), dan penilaian produk (product). Berdasarkan ketiga aspek tersebut, peneliti menemukan bahwa dalam penerapannya metode ini sangat cocok digunakan di Politeknik Negeri Madura mengingat pola pembelajarannya yang sangat menitikberatkan pada kasus nyata yang terjadi dengan segala pemecahan masalahnya. Hasil belajar yang telah ditemukan dalam penelitian ini adalah keaktifan atau adanya keikutsertaan mahasiswa dalam menggunakan Bahasa Inggris di dalam penyelesaian masalah-masalah yang telah ditentukan sebelumnya oleh peneliti. Hal ini disebabkan dalam penerapannya penilaian autentik tidak berfokus kepada penilaian secara tradisional semisal ujian.
\end{abstract}

Kata kunci: penilaian autentik, evaluasi, hasil belajar 


\section{PENDAHULUAN}

Proses belajar mengajar di politeknik sangatlah unik. Politeknik lebih menekankan proses belajar mengajar kepada praktik karena mahasiswa dituntut untuk lebih terampil dengan kemampuan yang berfokus pada bidangnya. Dalam hal ini, mahasiswa kuliah berdasarkan situasi nyata yang materinya telah dibuat sedemikian rupa oleh dosen. Oleh karena itu, ketika penilaian dilakukan dapat mengunakan penilaian autentik agar relevan dengan apa yang diharapkan. Penilaian autentik adalah metode penilaian yang sangat bisa diandalkan ketika pendidik ingin mengetahui proses selama belajar mahasiswa karena mahasiswa diberikan contoh kasus dalam kehidupan nyata.

Untuk mendapatkan pencapaian mahasiswa yang lebih objektif dalam aktivitas kelas tersebut, penerapan penilaian autentik dapat digunakan sebagai salah satu alternatif penilaian. Dengan tipikal penilaian ini diprediksikan mampu menyajikan gambaran atas hasil belajar mahasiswa. Penilaian autentik lebih terpusat kepada tugas-tugas rumit dan bersentuhan dengan kejadian nyata yang menjadi wadah untuk mahasiswa menunjukkan kompetensi mereka atau pemahaman yang didasari oleh ilmu pengetahuan. Penilaian autentik juga dirasa cocok dengan mata kuliah yang bersifat tematik dalam hal ini sesuai dengan English for Specific Purposes yang diterapkan di kampus Politeknik Negeri Madura.

Penelitian ini mengkaji secara detail mengenai penggunaan penilaian autentik sebagai evaluasi mata kuliah Bahasa Inggris 2 di Politeknik Negeri Madura, (1) bagaimana penerapan metode autentik pada mata kuliah Bahasa Inggris 2 dan (2) apa dampak metode penilaian autentik terhadap kualitas belajar mahasiswa pada mata kuliah Bahasa Inggris 2. Penelitian ini memiliki batasan yaitu hanya menggunakan tiga aspek (1) penilaian sikap, (2) penilaian kinerja, (3) penilaian produk.

\section{TINJAUAN PUSTAKA}

\section{Penilaian Autentik}

Pada umumnya di dalam evaluasi pembelajaran, penilaian dapat dipisahkan menjadi dua bagian, yaitu, penilaian tradisional dan penelitian autentik. Penilaian tradisional yang seperti pada umumnya dapat ditemui adalah penilaian dengan pola bagaimana mahasiswa menjawab atau menanggapi pertanyaan-pertanyaan yang 
diberikan oleh pengajar yang tentunya telah disusun terlebih dahulu dengan harapan para mahasiswa mampu menjawab pertanyaan-pertanyaan tersebut (Sani, 2016).

Penilaian autentik sendiri memiliki arti mengenai keaslian, valid atau yang sebenarnya serta juga dapat diandalkan (reliable). Jika dibandingkan dengan penilaian tradisional, penilaian autentik di dalam penerapannya menjadi lebih bermakna. Dengan demikian pengajar dapat menentukan materi apa saja yang sudah dapat dianggap layak untuk dilanjutkan serta materi apa saja yang seharusnya diulang. Di samping itu istilah penilaian autentik dibuat sebagai salah satu bentuk penilaian alternatif sehingga mahasiswa akan mampu menunjukkan penyelesaian masalah dan mengasah kemampuannya dalam penyelesaian tugas yang telah disusun oleh pengajar. Secara tidak langsung, mahasiswa juga dapat menampilkan pengetahuan dan keterampilannya dengan cara simulasi tentang situasi nyata di luar lingkungan belajar (Hymes, 1991). Ada tiga aspek yang mencakup hasil belajar pada penilaian autentik, yaitu aspek pengetahuan, sikap, dan keterampilan.

\section{Bentuk Penilaian Autentik}

Menurut Kusnanadar (2013) ada tiga bentuk penilaian autentik, yaitu penilaian kinerja, penilaian sikap dan penilaian produk. Masing-masing bentuk akan dijelaskan sebagai berikut.

1. Penilaian Kinerja

Di dalam penilaian kinerja, kegiatan mahasiswa ketika melaksanakan tugas yang disusun terlebih dahulu diamati oleh pengajar. Penilaian kinerja juga disebut sebagai penilaian yang sesuai jika digunakan untuk menilai ketercapaian kompetensi mahasiswa yang bersifat menunjukkan performa mahasiswa tersebut, contohnya adalah memeragakan presentasi dan juga praktikum di laboratorium maupun bengkel. Ada beberapa cara dalam penilaian kinerja guna mendapatkan aspek basis kinerja:

a. Daftar centang. Digunakan untuk mengetahui kemunculan atau tidak munculnya bagian-bagian tertentu dari indikator atau bahkan subindikator yang seharusnya muncul di dalam suatu aktivitas atau tindakan.

b. Catatan Anekdot/ narasi. Catatan ini digunakan ketika guru melakukan pencatatan narasi akan kegiatan mahasiswa selama pelaksanakan tindakan. Dari catatan 
tersebut, dapat diketahui apakah mahasiswa sudah memenuhi standar yang telah ditetapkan.

c. Skala Penilaian. Digunakan oleh pendidik untuk menggunakan skala numerik sekaligus dengan predikatnya. Misal, $5=$ excellent, $4=$ very good, $3=$ average, 2 $=$ poor, $1=$ bad .

d. Catatan Ingatan. Digunakan oleh pendidik untuk mengamati mahasiswa ketika sedang melakukan aktivitas tanpa menggunakan catatan. Walaupun tidak dapat disarankan, cara ini bisa menjadi bermanfaat ketika pendidik ingat akan kinerja mahasiswa yang selanjutnya menentukan sikap.

2. Penilaian Sikap

Penilaian sikap terdiri atas tiga komponen, ketiga komponen tersebut adalah afektif, kognitif, dan konatif. Afektif adalah perasaan seseorang atau penilaian seseorang terhadap suatu objek. Kognitif adalah kepercayaan seseorang atas objek tersebut dan konatif adalah kecenderungan untuk bersikap atau berperilaku dengan cara tertentu atas kedatangan objek sikap.

Penilaian sikap dapat dilaksanakan dengan berbagai cara atau teknik. Cara-cara tersebut adalah pengamatan perilaku, pertanyaan langsung, dan laporan individu.

Aspek penilain sikap memiliki lima tahapan proses berpikir, yaitu (1) memberi tanggapan, (2) menerima/memerhatikan, (3) menilai/menghargai, mengatur/menyusun dan (5) berkarakter (Kunandar, 2013). Yang perlu dinilai mengenai aspek sikap dalam proses pembelajaran adalah sikap terhadap mata pelajaran, sikap terhadap dosen/ pengajar, dan sikap terhadap proses pembelajaran.

3. Penilaian Produk

Penilaian produk adalah sebuah bentuk penilaian atas keterampilan dalam membuat suatu produk dan kualitas produk tersebut. Penilaian produk tidak hanya dilihat dan dinilai berdasarkan hasil akhir dari produk tersebut, tetapi juga dari proses yang terjadi dalam pembuatan produk tersebut. Penilaian produk pada umumnya menggunakan dua pendekatan. Pendekatan pertama adalah pendekatan secara holistik dan pendekatan kedua adalah pendekatan secara analitik. Pendekatan dengan cara holistik adalah berlandaskan kesan keseluruhan dari produk. Pendekatan dengan cara analitik 
didasarkan bagian-bagian produk, dilaksanakan terhadap semua kriteria yang terdapat pada semua tahapan proses pengembangan (Kunandar, 2013).

Penilaian produk memiliki tiga tahapan yang membutuhkan penilaian tiap tahapnya. Ketiga tahapan tersebut adalah sebagai berikut.

a. Tahap Persiapan. Menilai kemampuan mahasiswa dalam perencanaan, pengembangan, dan pendesainan dari produk yang telah ditentukan.

b. Tahap Pembuatan. Menilai kemampuan mahasiswa dalam penggunaan metode, teknik, dan juga alat-alat yang digunakan dalam membuat produk yang telah ditentukan.

c. Tahap Penilaian. Menilai kemampuan mahasiswa dalam membuat produk yang sesuai dengan kegunaannya dan memenuhi kriteria indikator yang akan dicapai.

\section{METODE PENELITIAN}

Penelitian ini dilakukan di Politeknik Negeri Madura yang berlokasi di Kabupaten Sampang, Madura. Partisipan dari penelitian ini adalah dosen pengampu mata kuliah Bahasa Inggris yang berjumlah tiga dan juga mahasiswa yang berada di Jurusan Teknik Bangunan Kapal, Politeknik Negeri Madura dengan total jumlah mahasiswa semester 2 kelas A maupun kelas B yaitu 32 peserta. Penelitian ini merupakan penelitan deskriptif kualitatif. Menurut Gay dan Airasian (2000: 275), penelitian deskriptif digunakan untuk melaporkan keadaan secara apa adanya. Itu artinya penelitian deskriptif bertujuan untuk mendeskripsikan situasi yang ada di lapangan secara sistematis dengan beberapa fakta yang terhubung dan tidak hanya mencari kebenaran absolut, tapi mencari pengamatan pemahaman. Selain itu, Matthews dan Kostelis (2011: 84) menyatakan bahwa penelitian deskriptif berusaha menjawab pertanyaan langsung tentang keadaan saat ini. Pernyataan ini mengacu kepada kondisi saat ini yang terjadi dalam penilaian autentik terhadap mata kuliah Bahasa Inggris 2 di Politeknik Negeri Madura.

Pengumpulan data pada penelitian ini menggunakan cara observasi. Metode ini digunakan ketika membutuhkan rekaman fenomena yang terjadi. Metode observasi juga sangat cocok digunakan untuk penelitian yang bertujuan mempelajari perilaku manusia dan juga proses kerja. Dengan definisi tersebut, observasi di sini mengamati aspek hanya dari tiga hal yang menjadi batasan pada penelitian ini, yaitu pengamatan akan aspek sikap, 
produk, dan kinerja mahasiswa. Observasi sendiri dilakukan tiga kali yang bertujuan untuk berfokus pada batasan penelitian. Selanjutnya, akan dilanjutkan dengan penganalisisan data secara mendalam dengan membentuk Focus Group Discussion (FGD) dengan rekan dosen pengampu mata pelajaran Bahasa Inggris lainnya yang telah tergabung menjadi team teaching, beserta dokumentasinya. Pembahasan mengenai temuan-temuan, yang telah disajikan di dalam proses observasi, akan dipaparkan di dalam FGD untuk melakukan hipotesis dan penyimpulan analisis data oleh ketiga dosen Bahasa Inggris tersebut. Sementara, teknik analisis data yang digunakan adalah metode analisis interaktif. Menurut (MIles, 1984), teknik analisis data ini adalah ketika peneliti berada di lapangan ataupun ketika kembali dari lapangan baru dilakukan analisis dengan mengikuti empat tahapan, yaitu (1) pengumpulan data (2) reduksi data (3) penyajian, data (4) penarikan kesimpulan.

\section{HASIL DAN PEMBAHASAN}

Berdasarkan hasil observasi yang selanjutnya hasil tersebut dijadikan data peneltian, bahwa 3 aspek yang menjadi fokus penelitian akan dijabarkan pada bagian ini.

\section{Aspek Penilaian Kinerja}

Pada aspek ini mahasiswa menunjukkan perubahan pola belajar di dalam kelas ketika dosen menyebutkan bahwa keaktifan di kelas menjadi poin penting dalam penentuan nilai mata kuliah Bahasa Inggris. Perubahan tersebut adalah hampir semua mahasiswa ingin berinteraksi dengan dosen ketika dosen menanyakan sesuatu yang berkaitan dengan materi kuliah pada saat itu. Hal ini menjadi perubahan yang sangat positif ketika proses belajar mahasiswa dinilai khususnya mata kuliah yang menekankan aktivitas berbicara seperti pada mata kuliah Bahasa Inggris. Pada aspek penilaian ini, peneliti telah menentukan indikator dari aspek penilaian kinerja. Indikator tersebut adalah bahwa dengan penerapan metode autentik ini, mahasiswa mampu berperan aktif menggunakan bahasa Inggris selama mata kuliah Bahasa Inggris 2 berlangsung. Subindikator yang diamati adalah kemauan mereka berinteraksi baik dengan dosen ataupun teman satu kelas dengan menggunakan bahasa Inggris. 


\section{Aspek Penilaian Sikap}

Di dalam penilaian sikap, peneliti memfokuskan pada pengamatan atas mahasiswa mengenai sikap mereka terhadap mata kuliah, sikap mereka terhadap dosen dan sikap mereka akan proes pembelajaran. Melalui lima tahapan penilaian di dalam menilai aspek sikap, peneliti telah merangkumnya pada fokus penilaian yang telah disebutkan di atas. Kelima tahapan tersebut adalah (1) memberikan respon atas pertanyaan-pertanyaan yang diberikan oleh mahasiswa (2) memperhatikan tingkah laku mahasiswa, seperti melarang mahasiwa untuk bertindak seenaknya di kelas, seperti bergurau dengan temannya sehingga membuat suasana kelas tidak kondusif dan kehilangan fokus belajar. (3) selalu memberi pujian kepada mahasiswa yang mampu menjawab pertanyaan dengan benar. (4) melarang mahasiswa untuk menggunakan segala jenis gadget ketika kuliah sedang berlangsung. (5) melarang mahasiwa untuk datang terlambat guna menghindari tertinggalnya pemaparan mata kuliah. Pada aspek penilaian ini, mahasiswa telah menunjukkan sikap yang kooperatif dan tidak melakukan pelanggaran yang disebutkan di atas. Pada hakikatnya, penilaian sikap digunakan sebagai acuan penambahan nilai di akhir semester. Mengingat penilaian autentik ini memfokuskan pada proses, penilaian sikap menjadi sangat krusial ketika pengajar dihadapkan pada perilaku sikap mahasiswa atau mahasiswa yang selalu menjadi bahan pembicaraan untuk penentuan nilai.

\section{Aspek Penilaian Produk}

Pada aspek penilaian ini, peneliti telah memberikan instruksi kepada mahasiswa untuk mengerjakan tugas-tugas yang sebelumnya sudah ditentukan. Tugas tersebut adalah tugas membuat poster mengenai reviu pembelajaran pada semester tersebut. Pada aspek penilaian produk ini, peneliti mengamati hasil akhir yang telah dibuat secara kelompok dengan memerhatikan komunikasi antaranggota kelompok kerja. Tentu saja dalam hal ini, peneliti tetap menginstruksikan agar mahasiwa menggunakan bahasa Inggris sebagai alat komunikasi ketika kegiatan diskusi dalam pembuatan produk di dalam kelompok. Dalam hal ini, peneliti menilai bahwa masing-masing mahasiswa telah berusaha untuk menggunakan bahasa Inggris sebagai alat komunikasi sehingga menjadi bahan pertimbangan peneliti untuk menentukan nilai yang terintegrasi dengan aspek penilaian kinerja. Pada tahap pertama atau tahap persiapan, peneliti telah memberikan beberapa 
instruksi kepada mahasiswa dalam pengerjaan tugas mereka. Dalam tahap ini, peneliti mengamati bagaimana mereka membagi tugas-tugas di tiap anggota kelompok. Selanjutnya, tahap kedua atau pembuatan. Seperti yang peneliti sampaikan di atas bahwa instruksi yang harus dipatuhi oleh mahasiswa adalah penggunaan bahasa Inggris dalam berinteraksi. Tahap terakhir adalah penilaian. Pada tahap penilaian, peneliti menilai produk mahasiswa secara analitik. Hal ini disebabkan peneliti ingin lebih mengamati respons mahasiswa akan instruksi-instruksi yang diberikan selama pengerjaan tugas daripada pengamatan tentang produk yang dihasilkan oleh mahasiswa secara holistik.

Aspek penilaian yang dilakukan oleh peneliti adalah tiga hal yang telah disebutkan di atas, aspek kinerja; sikap, dan produk. Penilaian kinerja digunakan oleh peneliti untuk menilai presentasi mahasiswa dalam presentasi bertema yang telah ditentukan sebelumnya. Di dalam penilaian produk, digunakan untuk menilai tugas yang mereka hasilkan dengan tema yang juga telah di tentukan sebelumnya. Penilaian sikap digunakan untuk menilai perilaku mahasiswa selama perkuliahan akan dimulai, sedang dilaksanakan, dan akan berakhir, termasuk bagaimana kehadiran mahasiswa, keaktifan berinteraksi dengan dosen, dan juga ketertiban mereka selama menjalani ujian baik harian maupun semesteran serta untuk menilai motivasi mahasiswa, kesopansantunan, dan tugas yang telah diberikan kepada mahasiswa.

\section{Kualitas Hasil Belajar}

Apakah penilaian autentik ini benar-benar menjadi metode yang tepat untuk digunakan didalam proses belajar Bahasa Inggris di Politeknik Negeri Madura dibandingkan dengan penilaian tradisional yang lebih menekankan kepada angka atau nilai akhir mahasiswa? Penilaian autentik jelas lebih cocok dan dibutuhkan di dalam proses belajar mengajar di lingkungan politeknik atau vokasi karena di dalam penilaian autentik lebih menonjolkan performa atau kinerja mahasiswa dalam penyelesaian masalah-masalah yang konkret atau nyata terjadi dalam kehidupan mahasiswa. Hal tersebut menjadi sangat tepat dan terintegrasi dengan pola pembelajaran di institusi vokasi yang selalu menyajikan pembelajaran praktik dan selalu nyata dengan keadaan atau kasus sebenarnya. Selain itu, ada beberapa kelebihan yang dimiliki oleh penerapan penilaian autentik dan keterkaitannya atas hasil belajar mahasiswa. Pertama, penerapan peniaian autentik dapat digunakan untuk mengukur secara langsung dan tidak langsung 
kinerja atau performa mahasiswa dalam proses belajar sebagai indikator capaian pembelajaran dalam hal ini pada mata kuliah Bahasa Inggris. Dengan penerapan penilaian autentik, mahasiswa dituntut untuk menunjukkan performa pada situasi nyata/riil yang telah ditentukan sebelumnya sehingga dosen dapat mengetahui bagaimana penguasaan materi mahasiswa secara langsung. Kedua, penilaian autentik menjadi unik karena dengan penilaian ini otomatis rangkaian belajar mengajar menjadi terintegrasi. Dimulai dari dosen memberikan pembelajaran, mahasiswa belajar, dan pengajar menilai hasil belajar menjadi satu kegiatan yang utuh dan tidak terpisah karena di dalamnya ada kegiatan penilaian autentik yang dituntut untuk menilai setiap performa mahasiswa. Dosen memberikan pekerjaan yang telah diatur semirip mungkin dengan dunia nyata sehingga mahasiswa menyusun sendiri dan dosen menilai tidak semata-mata dengan penguasaan materinya, tetapi performa yang diperlihatkan oleh mahasiswa. Ketiga, penilaian autentik terbuka untuk mahasiswa yang ingin menunjukkan hasil kerjanya atas tugas-tugas yang diberikan dengan metode yang mereka anggap paling tepat. Pada aspek ini, mahasiswa dapat secara langsung membuka peluang untuk faktor eksternal seperrti kreativitas dan penyelesaian masalah oleh mahasiswa sehingga proses belajar mengajar lebih menekankan kepada proses belajar bukan semata hasil belajar seperti nilai-nilai UTS dan UAS. Hal tersebut sangat tepat dan cocok dengan hakikat penilaian autenik yang menekankan kinerja.

Berdasarkan hasil dari pengamatan yang telah dilakukan di dalam penelitian ini, penilaian autentik tidak menitikberatkan kepada penilain yang bersifat nilai akhir atau penilaian semacam ujian, namun memfokuskan terhadap aspek aktivitas yang dilakukan mahasiswa selama mengikuti mata kuliah Bahasa Inggris 2. Ditemukan bahwa munculnya kemauan mahasiswa untuk ikut serta dalam setiap kegiatan yang sudah ditentukan, misal presentasi dan tugas kuliah yang dikerjakan secara bersama-sama. Dalam hal ini, yang dimaksud oleh peneliti adalah kemauan mahasiswa untuk menggunakan bahasa Inggris dengan kemampuan yang dimiliki masing-masing mahsiswa telah digunakan untuk penyelesaian masalah yang sudah ditentukan oleh peneliti sebelumnya. Penerapan metode penilaian autentik yang dirasa cocok dengan lingkungan politeknik atau vokasi telah membuat peneliti harus menyesuaikan materimateri dan pola pengajaran. Pengajar harus menentukan terlebih dahulu contoh kasus apa yang akan dibawa ke dalam kelas sehingga pengajar lebih mengurangi metode mengajar 
secara ceramah di dalam penerapan penilaian autentik. Munculnya kemauan untuk menggunakan Bahasa Inggris di dalam kelas memang bukan secara otomatis ketika peneliti menggunakan metode penilaian autentik. Melalui pengumpulan data yang dilakukan dengan melakukan observasi, peneliti dapat mengetahui bahwa ada beberapa mahsiswa yang tidak percaya diri dengan kemampuan Bahasa Inggrisnya sehingga tidak begitu yakin akan keikutsertaannya dalam diskusi maupun pekerjaan lainnya yang telah ditentukan oleh peneliti. Di sinilah peran peneliti yang sekaligus dosen menjadi sangat dibutuhkan untuk ketercapaian metode penilaian autentik. Dosen selalu memberikan kesempatan kepada mahasiswa-mahasiswa tersebut untuk terus mencoba berinteraksi dengan sesamanya atau semisal memberikan konseling dalam tugas presentasi sehingga pada prosesnya mereka akan menggunakan Bahasa Inggris sebagai bagian dari proses belajar pada mata kuliah Bahasa Inggris 2.

\section{SIMPULAN DAN SARAN}

Penerapan penilaian autentik dinilai sangat tepat penggunaannya di lingkungan Politeknik Negeri Madura yang merupakan salah satu institusi vokasi yang pola pembelajarannya sangat sesuai dengan penerapan penilaian autentik. Penilaian autentik sangat dibutuhkan ketika dosen ingin menilai mahsiswa secara performa dengan penerapan pembelajaran yang materinya sesuai dengan contoh kasus nyata atau konkret. Pada penerapannya, penilaian autentik di lingkungan Politeknik Negeri Madura dinilai sangat efektif dengan menekankan tiga aspek penilaian, di antaranya penilaian kinerja, penilaian sikap, dan penilaian produk.

Berikut adalah penjabaran mengenai hasil analisis peneliti. (a) Aspek Penilaian Kinerja. Pada aspek ini mahasiswa menunjukkan perubahan pola belajar di dalam kelas, ketika dosen menyebutkan bahwa keaktifan di kelas menjadi poin penting dalam penentuan nilai mata kuliah Bahasa Inggris. Perubahan tersebut adalah menurut Kusnanadar ada tiga bentuk penilaian autentik hampir semua mahasiswa ingin berinteraksi dengan dosen ketika dosen menanyakan sesuatu yang berkaitan dengan materi kuliah pada saat itu. Hal ini menjadi perubahan yang sangat positif ketika kita menilai proses belajar mahasiswa khususnya mata kuliah yang menekankan aktivitas berbicara seperti pada mata kuliah Bahasa Inggris. Pada aspek penilaian ini, peneliti telah 
menentukan indikator dari aspek penilaian kinerja. Indikator tersebut adalah bahwa dengan penerapan metode autentik ini mahasiswa mampu berperan aktif menggunakan Bahasa Inggris selama mata kuliah Bahasa Inggris 2 berlangsung. Subindikator adalah kemauan mereka berinteraksi baik dengan pengajar ataupun teman satu kelas dengan menggunakan Bahasa Inggris.

(b) Aspek Penilaian Sikap. Di dalam penilaian sikap, peneliti memfokuskan pada pengamatan atas mahasiswa mengenai sikap mereka terhadap mata kuliah, sikap mereka terhadap dosen dan sikap mereka akan proes pembelajaran. Melalui 5 tahapan penilaian di dalam menilai aspek sikap, peneliti telah merangkumnya pada fokus penilaian yang telah disebutkan di atas. Kelima tahapan tersebut adalah (1) memberikan respon atas pertanyaan-pertanyaan yang diberikan oleh mahasiswa (2) memperhatikan tingkah laku mahasiswa, seperti melarang mahasiwa untuk bertindak seenaknya dikelas, seperti bergurau sendiri dengan temannya sehingga membuat suasana kelas tidak kondusif dan kehilangan fokus belajar. (3) Selalu memberi pujian kepada mahasiswa yang mampu menjawab pertanyaan dengan benar. (4) Peneliti juga melarang mahasiswa untuk tidak menggunakan segala jenis gadget ketika pelajaran sedang berlangsung. (5) Peneliti juga melarang mahasiwa untuk datang terlambat ke dalam kelas guna menghindari tertinggalnya pemaparan mata kuliah. Pada aspek penilaian ini mahasiswa telah menunjukkan sikap yang kooperatif dan tidak melakukan pelanggaran yang disebutkan di atas. Pada hakikatnya adalah, penilaian sikap digunakan oleh pengajar untuk dijadikan acuan penambahan nilai di akhir semester, mengingat penilaian autentik ini memfokuskan pada proses, maka penilaian sikap menjadi sangat krusial ketika pengajar dihadapkan dengan perilaku sikap mahasiswa atau mahasiswa yang selalu menjadi bahan pembicaraan untuk penentuan nilai.

(c) Aspek Penilaian Produk. Pada aspek penilaian ini peneliti telah memberikan instruksi kepada mahasiswa untuk mengerjakan tugas-tugas yang sebelumnya sudah ditentukan. Tugas tersebut adalah tugas membuat poster mengenai reviu pembelajaran pada semester tersebut. Pada aspek penilaian produk ini peneliti mengamati hasil akhir yang telah dibuat secara kelompok dengan memperhatikan komunikasi antar anggota kelompok kerja. Tentu saja dalam hal ini peneliti tetap menginstruksikan agar mahasiwa menggunakan Bahasa Inggris sebagai alat komunikasi ketika kegiatan diskusi dalam pembuatan produk di dalam kelompok. Dalam hal ini peneliti menilai bahwa masing- 
masing mahasiswa telah berusaha untuk menggunakan Bahasa Inggris sebagai alat komunikasi sehingga menjadi bahan pertimbangan peneliti untuk menentukan nilai yang terintegrasi dengan aspek penilaian kinerja. Pada tahap pertama atau tahap persiapan, peneliti telah memberikan beberapa instruksi kepada mahasiswa dalam pengerjaan tugas mereka. Dalam tahap ini peneliti mengamati bagaimana mereka membagi tugas-tugas pada tiap anggota kelompok. Selanjutnya adalah tahapan kedua atau pembuatan. Seperti yang peneliti sampaikan di atas bahwa instruksi yang harus dipatuhi oleh mahasiswa adalah penggunaan Bahasa Inggris dalam berinteraksi. Sedangkan tahapan terakhir adalah penilaian. Pada tahap penilaian, peneliti menilai produk mahasiswa secara analitik. Hal ini disebabkan peneliti ingin lebih mengamati respon mahasiswa akan instruksiinstruksi yang diberikan selama pengerjaan tugas ketimbang pengamatan tentang produk yang dihasilkan oleh mahasiswa secara holistik.

Meskipun begitu masih ada beberapa aspek penilaian yang belum bisa diaplikasikan oleh peneliti. Aspek-aspek tersebut adalah penilaian proyek, penilaian portofolio dan juga penilaian diri. Hal dini disebabkan keterbatasan waktu yang dimiliki oleh peneliti dan juga banyak yang harus diperhatikan secara detail pada aspek-aspek pembahasan tersebut.

Ada beberapa kendala yang ditemui oleh peneliti ketika proses penerapan penilaian autentik diterapkan. Pertama, penilaian autentik membutuhkan waktu yang cukup banyak, dan juga konsistensi peneliti dalam penerapan penilaian autentik. Ke depannya penelitian akan menindaklanjuti kekurangan di dalam penelitian ini. Kekurangan yang dimaksud adalah penerapan beberapa aspek penilaian autentik yang tidak dilakukan oleh peneliti

\section{DAFTAR PUSTAKA}

Airasian, G. a. (2000). Educational Research: Competencies for Analysis and Application. New Jeresey: Pearson Education.

Asrul. (2014). Evaluasi Pembelajaran. Bandung: Cipta Pusaka Media.

Hymes. (1998, February 1). Oregonstate.edu. Retrieved from Oregonstate: http://oregonstate.edu/instruction/ed555/zone5/auth.htm

Kostelis, M. a. (2011). Designing and Conducting Research in Healt and HUman Performance. San Fransisco: John Wiley and Sons, Inc. 
Kunandar. (2013). Penilaian Autentik (Penilaian Hasil Belajar Mahasiswa berdasarkan Kurikulum 2013). Jakarta: Raja Grafindo.

MIles, M. \&. (1984). Qualitative Data Analysis. London: Sage.

Sani, R. (2016). Penilaian Autentik. Jakarta: Bumi Askara. 